\title{
"There is no magic whereby such qualities will be acquired at the voting age": Teachers, curriculum, pedagogy and citizenship
}

\author{
Lorna McLean* \\ University of Ottawa
}

\section{ABSTRACT}

This study asks: What did it mean to be a Canadian citizen in the late forties and fifties? Who were considered good citizens, what were their qualities, and how did the teaching of citizenship relate to notions of identity, nation(alism), belonging and international development within a postwar liberal democracy? Finally, how did educational and policy materials as reflected in the curriculum and pedagogy of the day represent citizenship? Recent studies of this period emphasize diversity and dissent among educators who challenged the status quo, despite pressures to conform to societal norms and to produce workers with skills and attitudes that would benefit the modern economy. This research on citizenship, youth, and democratic education suggests reasons to re-evaluate our understanding of what is considered the legitimate domain and purpose of citizenship education along with the possibilities of teaching citizenship within a school/classroom setting.

\section{RÉSUMÉ}

Cette étude demande : Que signifiait être citoyen canadien durant les années quarante et cinquante? Qui étaient considérés comme bons citoyens, quelles qualités possédaient-ils et quels étaient les rapports entre l'enseignement de la citoyenneté et l'identité, la nation et le nationalisme, l'appartenance et le développement international dans la démocratie libérale d'aprèsguerre? Enfin, comment les principes de l'éducation, inscrits dans le curriculum et la pédagogie de l'époque, ont-ils représenté la citoyenneté? Des études récentes sur cette période ont mis l'accent sur la diversité et la dissidence parmi certains éducateurs qui ont contesté le statu quo, malgré les pressions les invitant à se conformer aux normes sociétales et à former des ouvriers dont les connaissances et les attitudes devaient profiter à l'économie moderne. Cette recherche sur la citoyenneté, la jeunesse et l'éducation à la démocratie propose une réévaluation de notre compréhension de cet enseignement qu'est l'éducation à la citoyenneté, ainsi que les façons de l'enseigner en classe.

\footnotetext{
* The author sincerely thanks Alessandra Iozzo-Duval, Kelly Brand and Heather Brittain for their diligent research.
} 
I want my students to be aware of the world and its problems. I want them to be trained, and able, to take their share in good creative living, at community, national, and international levels. And I know that if they are to do this they must learn in their youth to take responsibility, to bear willingly their share of the tasks to be done, to live in mutual respect with others. These things must happen in my own classroom. There is no magic whereby such qualities will be acquired at the voting age. ${ }^{1}$

— Blanche Snell, teacher, York Memorial Collegiate, 1929-1961.

Blanche Snell was an exceptional teacher. In the early 1950s, she taught English, Social Studies, and Guidance for three hours each day to a class of 25 grade 9 students. She began her course by discussing what each student hoped to get out of the year at high school. Together, they outlined the rights and responsibilities of each member of the group, including the teacher. They documented their decisions and agreed upon the principles by which they would work. Students divided up tasks and set up a planning committee. At first, Miss Snell reported, "it appears sheer fun. Shortly after it becomes full of serious problems.... so, with the ups and downs, we go through the year, trying to understand why we behave as we do, trying to become self-motivated and controlled." 2

In a subsequent article on curriculum planning, Miss Snell wrote about studentcentred learning: "The teacher who cannot stand commotion and has little patience, who is unable to fail and start again, who cannot give others the right to plan, who cannot, after initial failures, continue to have faith in the capacity of youth to use good judgement, is not the one to attempt this type of teaching. It is a kind of teaching to be believed in, not legislated into. Once attempted, there is no turning back." ${ }^{3}$ In evaluating the effectiveness of her approach, Miss Snell was modest: "The only evidence of difference, at the moment, is the unsolicited incidental comment [by former students], for they drop in to chat, and when in larger groups we draw together as if by instinct." She elaborates further, "To attempt to measure this kind of learning is to attempt to assess the intangible. The culmination of the test will come only when we see these young people as adults, assuming their share of the world's tasks." 4

In addition to her work in the classroom Miss Snell sought to influence students' interests beyond Canadian borders by forming a United Nations Club in the 1950s and organizing a United Nations Model Assembly, wherein students were faced with the "problem of learning the points of view of the countries they represented, of conducting discussion in true United Nations manner, and of familiarizing themselves with the U.N. charter." Preparation for the Assembly entailed a good deal of work under the guidance of their teachers. ${ }^{5}$ To further develop their understanding of international issues, in 1959, Miss Snell sponsored a radio broadcast involving four students from two schools to discuss the topic "Should Canada increase its aid to the underdeveloped countries in the world?" 6 Furthermore, she spearheaded projects to support education around the world; for example, her school raised \$1,000 for the Pubvnan Technical School fund in Korea. ${ }^{7}$ Blanche 
Snell's advocacy for what would be termed today global education or global citizenship education extended beyond fund-raising projects in schools, however. In 1960, she was one of several judges invited to select the winners of the Agnes Macphail essay contest, which was sponsored by the Women's International League for Peace and Freedom. ${ }^{8}$

I highlight Miss Snell's life story here because her insights about citizenship, youth, and democracy suggest reasons to question what it meant to be a good citizen in Canada in the late 1940s through to the 1950s. This study of formal citizenship education for adolescents offers an opportunity to explore how citizenship training related to notions of identity, nationalism, belonging and global citizenship education within a postwar liberal democracy. To better understand these relationships, I applied a critical discourse analysis to the Ontario curriculum and pedagogical materials, reviewed promotional materials prepared by the federal government (including the CBC Archives website and the records of the Canadian Council for Reconstruction through UNESCO), analyzed a collection of high school yearbooks and studied the publications of the Canadian Teachers' Federation (CTF), and the Ontario Secondary School Teacher's Federation (OSSTF) over two decades. This research on formal citizenship education and youth suggests reasons to re-evaluate our understanding of what is considered the legitimate domain and purpose of citizenship education along with the possibilities of teaching citizenship within a high school setting.

While other scholars have examined the nature of education in this time period, ${ }^{9}$ extra-curricula activities, ${ }^{10}$ the role of the federal government, ${ }^{11}$ teachers' experiences, ${ }^{12}$ and how notions of citizenship have intersected with diversity, ${ }^{13}$ as yet, no one has probed the way in which these multiple experiences inform the nature of citizenship education, post-war ideals and objectives for Canadian national and international identity, especially as they pertain to young people. For this research, I draw upon the theoretical framework of historian Kenneth Osborne. According to Osborne, four themes dominated the teaching of citizenship in the social studies curriculum in the twentieth century: identity, political efficacy, rights and duties, and social and personal values. ${ }^{14}$ Throughout the postwar period, the emphasis on rights and duties, and social and personal values dominated education, alongside a sustained attention to issues of national identity and, to a lesser extent, political efficacy.

Like Miss Snell, Osborne believes that citizenship must be learned: "It is based on a body of knowledge, skills and values that can never be taken for granted.... This is what makes schools so important.... [democracy depends on] the existence of a vital civil society - that network of non-political institutions (unions, associations, clubs, organizations of all kinds) in which people participate and practise such democratic skills as holding office, dealing with disagreement, working with others, exercising tolerance, and so on. In other words, democratic activity takes place in two settings: the formal institutions of the state and the ostensibly non-political life of civil society." ${ }^{15}$ This article will explore the formal and quasi-government institutions of the state; a second follow-up study will examine informal associations and youth groups. 


\section{Introduction}

Increasing nationalism and unity in post-World War II Canadian society encouraged burgeoning interest in Canadian citizenship and education, leading to the introduction of a new Citizenship Act on January 1, 1947. ${ }^{16}$ Secretary of State Paul Martin signalled this enthusiasm in the House of Commons when he declared, "[c]itizenship means more than the right to vote; more than the right to hold and transfer property; more than the right to move freely under the protection of the state; citizenship is the right to full partnership in the fortunes and the future of the nation." ${ }^{17}$ The belief that citizenship was an instrument of nation-building underlay the 1947 Act. ${ }^{18}$ Canadians shared a sense of urgency for teaching citizenship among the youth of the day. C.R. MacLeod, a professor at the Normal School in London, Ontario, captured this sentiment in the introduction to his 1949 book, Citizenship Training: A Handbook for Canadian Schools: "THE WORLD TODAY, is faced with a crisis - a crisis in human relations. Educators are becoming more and more conscious of the responsibility of schools to help overcome this crisis." ${ }^{19}$ The threat of a "crisis" was, and is, used frequently to frame the rhetorical approach of citizenship education projects, but, in this instance, given the devastation of World War II, for many it was also a reality.

Equally important was the adoption of the Universal Declaration of Human Rights by the United Nations on December 10, 1948. It espoused non-discrimination based on race, colour, sex, language, religion, and politics. Its impact on society and global citizenship education is worthy of further consideration. During the parliamentary hearings on human rights in 1947 and 1950, "measures were justified on the basis that they would provide better protection of basic rights and would help to educate citizens in the values of tolerance and mutual respect of rights." ${ }^{20}$ Likewise, Christopher MacLennan argues that " $[\mathrm{t}]$ he international concern in the $1940 \mathrm{~s}$ and $1950 \mathrm{~s}$ for universal human rights invaded not only the conference rooms of the United Nations but also the newsrooms, classrooms and living rooms of Canadians." 21

Profound demographic shifts and population growth following World War II contributed to the growing sense of urgency for educating newcomers to become good citizens. Canada's population expanded from 12.1 million in 1945 to 18.2 million in 1961. Part of this increase was due to the 1946-62 baby boom: more than a demographic category, this "generation" acquired a social and political dominance that would define the 1960s in profound ways. ${ }^{22}$ However, the arrival between 1951 and 1956 of 791,930 immigrants, ${ }^{23}$ including persons displaced by the war, also contributed to growth. Their impact on Canadian culture was due not only to their numbers but also their origins: in the immediate postwar years, most came from Britain; between 1948 and 1951, many also arrived from eastern Europe. From 1951 to 1957, there was increased immigration from northern and western Europe, while origins shifted to southern Europe between 1958 and 1961. National security concerns, heightened by the cold war and the revelation of Soviet espionage by Igor Gouzenko in 1945, affected immigrants suspected of having communist sympathies. ${ }^{24}$ As well, there is some evidence to suggest that cold war fears may have shaped 
the way teachers approached topics such as citizenship.

As the country was also becoming more urbanized, immigrants were drawn to urban areas where the population of students burgeoned. Of the 1,055,818 nonCanadian citizens in 1961, about 70 percent lived in metropolitan areas with a population of 100,000 or more, and 70 percent of these were located in the three largest metropolitan areas. ${ }^{25}$ Ontario was increasingly attractive. ${ }^{26}$ The population growth had significant implications for education: between 1946 and 1961, elementary enrolment jumped 116 percent and secondary placements by 141 percent. The number of classrooms in Ontario doubled, and school boards launched recruiting drives for teachers from across Canada and Britain. ${ }^{27}$

\section{The Federal Government}

In keeping with Liberal Prime Minister St. Laurent's stated goal of “making Canadian citizens of immigrants and making Canadian citizens of as many as possible of the descendants of the original inhabitants of this country," ${ }^{28}$ in January 1950, the government created the Department of Citizenship and Immigration, with four central offices including the Citizenship Branch. ${ }^{29}$ The Branch was responsible for promoting knowledge of Canada — its society, institutions, culture, and languages — among Canadians and newcomers through educational, training, and community development projects. ${ }^{30}$ As Cynthia Commachio observes in her study of youth from the period, "public discussions about youth labour emphasized training, not merely in terms of job-related skills, but just as much in terms of character formation, selfmanagement, and citizenship, the latter encompassing these other individual traits in their most expansive productive sense. Canada's youth held the key to its national prosperity and to its international standing." ${ }^{31}$ Unlike many other western countries that have enacted federal citizenship policies - Australia and the United States, for instance - Canada does not have a national or federal bureau of education. ${ }^{32}$ Despite the lack of a government agency, and the positioning of educational jurisdiction within provincial boundaries, the federal government's flourishing bureaucracy pursued dynamic strategies to shape citizenship education among Canadian high school students. Along with funding research and training teachers, the federal government co-operated with the provinces in developing materials. As Alan Sears contends as "the state used the argument of compelling national interest to override constitutional niceties and influence aspects of Canadian citizenship education." 33

From the 1940 s to the 1960 s, thousands of booklets and filmstrips designed to introduce immigrants to Canada were distributed through immigrant language classes and volunteer organizations for use with both immigrants and Canadian youth. ${ }^{34}$ As a case in point, in the 1950s and again in the early 1960s, the Department of Citizenship and Immigration and distributed a discussion guide titled "Let's Take a Look at Prejudice." ${ }^{35}$ The supplementary reading list targeted social and personal values, tolerance, respect for minorities, and compassion - the hallmarks of liberalism. The ideological orientation of the guide which depicted prejudice as a state of mind and discrimination as the action offered suggestions for denouncing societal failings 
through education, legislation and community action combined with workshops to study the Canadian Bill of Rights. Such materials shared a common view of the time that prejudice and discrimination were "learned" and therefore could be "unlearned" through effective teaching strategies.

The federal government attempted to ensure that it did not overstep jurisdictional bounds by using "surrogate" organizations such as the National Film Board (NFB) or Canadian Broadcasting Corporation (CBC) and provincial programs to carry out citizenship education. Because of their quasi-government status, surrogate organizations could tackle more controversial issues and take greater risks than an elected government: for example, John Grierson, NFB director, "was certain that a powerful national experience could be kindled through the medium of film." Appointed by Prime Minister King, Grierson sought to develop the NFB as, in his words, "'more of a Ministry of Education than anything else," in which "the new citizenship of the co-operative state is even now, in spite of confusion, asking to be articulated." 36 By the 1940s, NFB films promoted working in and for the community locally, nationally, and internationally. Films such as Lessons in Living (1944) featured public school settings to articulate the "new citizenship of the co-operative state." 37 Youth Is Tomorrow (1939), one of the NFB's first documentaries, encouraged youth in the post-depression world to think globally; postwar films such as Tomorrow's Citizens (1947) promoted themes of world citizenship. By the 1950s, the NFB was producing documentaries on racism and prejudice for use in schools and amongst community groups. ${ }^{38}$ One example, No Longer Vanishing, promoted citizenship among Canada's First Nations and featured First Nations integration into Canadian society.

Throughout this period, the federal government marshaled its spending power to induce the provinces to offer programs consistent with federal citizenship policy and to build the capacity to carry out that policy in public schools. Although the provinces complained that the conditions attached to federal money "constituted undue interference by the federal government in a provincial area of responsibility," they did not refuse the funds. ${ }^{39}$ Surrogate organizations, which relied on state resources to carry out citizenship education, extended the capabilities of the relatively small federal department by venturing into areas beyond the state's reach. The Federation of Women's Teachers' of Ontario (FWTAO) offers one such example. The February, 1947 issue of the FWTAO's publication, The Educational Courier, featured an article which recommended "visual aids on intercultural relations" prepared by the Citizenship Branch with the NFB on topics such as "Peoples of Canada." 40

Attempts at influencing educational practice in the schools drew upon other forms of media to garner attention among youth. Working alongside the Canadian Association for Adult Education (CAAE), the CBC broadcast the national radio program Citizens' Forum, which modelled interactive, progressive forms of education that instructed the audience on basic civic literacy skills and provided opportunities to apply these skills through participation in civic affairs. The program, which began in 1945, continued for 12 years and was later adapted for television. Although the program was intended for adults, weekly panel debates were transmitted from different provinces at various locations, including schools, where they were often held 
in conjunction with the Home and School Association. Topics ranged from national issues such as the death penalty to the question of "how we acquire prejudices." NFB documentaries on related topics were announced in the Citizens' Forum Bulletin, which included background information "as well as opposing views and attitudes and suggestions for further reading." 41

Experienced educators, like Miss Snell, contributed their pedagogical and curriculum expertise as part of the Citizens' Forum organizational team. Among the representatives on the Forum's committee were a number of teachers, including Emma Carr, who resigned as secretary of the FWTAO in 1944 to become secretary of the Forum, and later Evelyn MacDonald, a teacher from Bloor Collegiate Institute who represented the CAAE. ${ }^{42}$ Not surprisingly, teachers took advantage of the programs by incorporating them into their classroom planning. Miss Rutherford, a secondary teacher in Kirkland Lake, joined the Citizen's Forum and devoted a weekly history class to a discussion of the issues raised by the broadcasts. ${ }^{43}$

The Citizens' Forum and the NFB offer evidence of critical civic engagement among quasi-governmental organizations that provided a pedagogical model for public debate through documentaries and radio broadcasts, much as today's blogs or interactive social networking websites do. As Janine Brodie reminds us, in postwar states "social liberalism prescribed that all citizens could make claim to a measure of equality, social security, and collective provision as a right of citizenship, independent of their status in the market or their personal character. Social citizenship required positive obligations from the collective to provide resources for the welfare of individuals." ${ }^{44}$ While the Citizens' Forum and the NFB did not focus solely on citizenship education, they did succeed in addressing issues of (in)equality, social justice and international development by modeling innovative models of instruction for teaching citizenship literacy skills and for generating public debate subscribing to the belief that personal enlightenment might or might not lead to action. ${ }^{45}$

\section{Provincial Curriculum and The Good Citizen}

Throughout the fifties, citizenship education was a primary focus of the social studies curriculum. In Alberta, for example, it "encompassed a wide range of desirable outcomes, from 'displaying democratic attitudes and behaviours in all social situations' to 'developing consumer competence."' 46 In Nova Scotia, the Guidelines on Citizenship took a more pragmatic approach and stated that "People must not only know what constitutes good citizenship, they must practice being good citizens." Citizenship was taught in schools: assigned tasks required students to make a list of the important qualities of a good citizen. ${ }^{47}$ Articles in the federations' publications, The Education Courier and The Bulletin promoted teaching intercultural relations as part of the curriculum to help students overcome fears of other people. ${ }^{48}$

According to the Ontario Intermediate Division, 1951 Curriculum: Grades VII, $V I I I, I X, X$, "Social Studies is the study of man [sic] in relationship to his environment and to other people. This central theme embraces in one subject history, geography, civics, and guidance.... Social Studies should help the pupils to understand 
and to improve the democratic way of life.... We must define and meet our responsibilities to society more effectively." ${ }^{49}$ Much like the categories suggested by Osborne, the curriculum set out four themes: knowledge and understanding, skills, attitudes, and behaviour - with few references to political efficacy. ${ }^{50}$ Knowledge and understanding encompassed values of tolerance and respect. ${ }^{51}$ Skills included critical thinking and group discussions, but not, interestingly, preparing an argument, debating, or other forms of dissension - abilities that are part of the democratic process. The component of the curriculum incorporating attitudes called for respect unprejudiced by qualities of race, colour, class, creed, or national origin, but said nothing about discrimination; gender was not mentioned. Finally, "acceptable social behaviour" included "cooperation with individuals and groups without regard to nationality, religion, or social position."

Curriculum is written by educators and sanctioned by the ministry. Like texts, curriculum is produced out of, and is positioned "within complex sets of relationships and processes in particular times and places." 52 The social studies curriculum's guiding principles frame my analysis: "It is better for pupils to find out the information for themselves and draw conclusions under the teacher's guidance than to have information given to them. The habit of judgement can be fostered in pupils by leading them to think and reason for themselves....; Democracy should be presented not as an ideal which has been attained but as a desirable way of life in which improvements are continually being sought; and Citizenship is not a subject to be taught but a spirit to be engendered. Social Studies provides many opportunities for arranging activities which develop the qualities of good citizenship." 53

To better understand how the curriculum represented citizenship in relation to nationalism and belonging alongside Osborne's four themes of identity, political efficacy, rights and duties, and social and personal values I selected key topics across all grades of the 1951 Ontario secondary social studies curriculum from history, geography, government of Canada, world history, and present-day global political, economic, and social relationships. To analyze the textual content, I drew upon Walt Werner's eight concepts for interpreting authorship in texts: representation, the gaze, voice, intertextuality, absence, authorship, mediation and reflexivity. ${ }^{54}$ For a definition of progressive education, I base my understanding on student-centred learning theory, which focusses on studying contemporary problems to better prepare children for the real world through interactive, experiential classroom learning experiences. I define a more traditional approach as teacher-centred, with structured teacher-led lessons focussing on textbook assignments based on literacy competencies.

The grade 7 social studies curriculum on "Living in a Democracy" introduces its objective "To appreciate the freedoms we enjoy." The curriculum speaks from the perspective of those who have benefitted from "Our freedoms." Under "our freedoms" (emphasis mine) students are invited to "collect newspaper clippings which illustrate our possession of these freedoms." 55 Nowhere are students asked to search out examples of "people" who do not share "our" freedoms," such as First Nations, African Canadians, or women. In fact, the possessive "our" explicitly marginalizes dissenting voices. The accompanying exercise instructs teachers to "read or dramatize 
events in Canadian history by which these freedoms were won." The implicit interpretation of such an activity champions a past history of hard-won freedoms, not deplorable losses, such as the then-recent, government-imposed, forced relocation of Japanese-Canadians.

In the grade 8 curriculum, titled "How the British People Laid Foundations for Our Social Life," the objectives centre around the larger narrative of imperialism, privileging the "contribution of British standards of conduct." ${ }^{56}$ Likewise, under the section "How Britain Laid the Foundation for Modern Industry," students are directed to research the topic and "appreciate Britain's contribution to the world in developing modern industry, transportation, and communication"; there is no question that Britain's contribution is anything but worthy of celebration. Although the goal of teaching students about "the social problems which arise from industrialization" offers opportunities to denounce unequal power relations and worker dissent, there are only two opportunities for such discussions: the directive to "Dramatize complaints of a merchant about goods" conceals a power imbalance between merchants and workers; the assignment to "list improvements that have been made in factory and home conditions of the worker of today" deflects attention from the workers' historic contempt, to the "improved" conditions of modern society.

The topic of slavery in grade 9 appears under the unit title "How the American people occupied half a continent and preserved their unity." ${ }^{7}$ Title, subtitles, and pedagogical tasks circumscribe slavery within a storyline of American nation-building and economic expansion. The unit first focusses on the labour demands of the cotton industry with recommendations for students to "show how Whitney's cotton gin increased the demand for slaves," and explain why "In the South cotton was king." Thus, when slavery is introduced, it is positioned first as an American, economic (rather than moral) issue, and then within the freedom movement (thus linking Canada with freedom): "How did the underground railway operate? Why was Windsor a terminal?" The day-to-day degrading experiences of slavery are represented only by the bewildering directive to "Dramatize a slave auction scene." It is uncertain how this unit might teach "democracy ... not as an ideal which has been attained but as a desirable way of life in which improvements are continually being sought," given the orientation of the research assignments.

For the study of First Nations, the curriculum introduces students to "Indians" under the topic "How the environment affected our earliest inhabitants"; ${ }^{58}$ the objectives do not identify who these "inhabitants" were. Rather, the prominence of place, not people, is reinforced by two themes: first "to understand the broader geographical features of Canada and to examine the ways in which this environment affected life in typical regions"; and second, "to appreciate the culture of these early inhabitants." Although the topics open up the possibility of discussing "differences that are not seen as inferior" when students are invited to "report what they know of Indian life from previous reading and from first hand knowledge," there is limited opportunity to develop this theme because the following assignment has students "contrast the natural conditions in the area of those times with its present state by means of a picture display" and "make a sand-table display of a typical area." After dealing with 
topics related to "how the open plain shaped its own particular pattern of living," students "attempt a discovery of the ways in which members established social customs, enforced order and justice" (my emphasis); the unit then concludes with the section "the Indian as a citizen of Canada today." ${ }^{59}$ Here, students are encouraged to explore categories of analysis that prescribe particular assumptions about integration: occupations, health, famous Indian citizens, and reservations. Finally, the invitation for pupils to collect "items from newspapers" and investigate "the citizenship status of Indians" creates a key learning moment to teach "respect for people and individuals unprejudiced by qualities of race, colour, class.”

As Werner notes, texts do more than convey facts; they represent power by privileging some voices and silencing others. Curriculum authors decide what gets put in and what is left out. ${ }^{60}$ With few exceptions, women of any race, colour, or creed are not represented as historical actors in the 1951 curriculum. Likewise, Canadian men and women of African, Chinese, Japanese, Indian, and many European nationalities are not represented, despite their long-term presence in Canada. Although curriculum units on the "Local Community" and "How Different Peoples Formed One Nation" invite teachers "to identify the national origins of families represented in the class" and "review ethnic groups found in your class or community," it would have been difficult for many of these pupils to see their identity represented in the curriculum. Thus, despite progressivist policy aims and guidelines governing student-centred learning, the 1951 curriculum presented Canadian identity and values through a storyline of national progress and linear social, economic, and political developments. At the same time, however, the range of topics and pedagogical strategies also offered creative space for teachers like Miss Snell to challenge these exclusionary narratives.

\section{Pedagogical Practice}

The diversity of approaches to teaching social studies across Canada has been the topic of much debate. Some historians claim that the 1950 s were conservative years in education while others have seen opportunities for progressive practices. Bob Gidney states that "Progressivism made far less headway in Canada ... still it provoked equally fierce opposition in newspapers, magazines, and speeches from both educators and the laity" ${ }^{61}$ as evidenced by Hilda Neatby's much-quoted So Little for the Mind. While Penny Clark has observed that, because social studies had been introduced during the progressive era of the 1930 s, it was frequently seen to be child-centred. ${ }^{62}$ In her study of social studies curriculum in twentieth-century Alberta, Amy von Heyking concludes that "It was simply impossible to find a synthesis of traditional and progressive approaches in a subject area that was progressive by its very nature." ${ }^{63}$ More recently, Paul Axelrod called for historians of education to consider an analysis beyond the paradigms of progressive/traditional polarities to a more nuanced understanding of education in the fifties. ${ }^{64}$ Reva Josee and Lauri Johnson's study is an example of this approach. Their study of the Welland Citizenship Program, which was adapted from the Springfield Plan, in Massachusetts concludes that this Plan which connected values of cultural diversity with tolerance and citizenship was taught for several years in 
northern Canadian schools and communities and contributed to "a pivotal time in the development of diversity and equity policies in Canada." ${ }^{65}$ As well, from other sources we know that the film, It Happened in Springfield, was promoted across Ontario by the teachers' federation as an instructive model for "Teaching good citizenship to youngsters.... [through] interest and enlist[ing] sympathy." 66

It is difficult to determine the extent to which any teacher, as exemplified in the profile of Blanche Snell, practised student-centred learning strategies. As Kathleen Weiler has observed, in the classroom people can "assert their own experience and contest or resist the ideological and material forces." ${ }^{67}$ Von Heyking reports that, in Alberta, "There is some evidence that... teachers were slowly incorporating some of the new techniques." ${ }^{8}$ However, a 1960s survey "found that most teachers relied on lecturing, question and answer, class discussion and written exercises.... classroom discussions were usually around material presented in textbooks." ${ }^{69}$ In Ontario, a study of teaching in the sixties confirmed a teacher-centred approach, relying heavily on textbook assignments. ${ }^{70}$ While progressive methods were a subject of debate in the Toronto school boards between 1948 and 1951, implementation of such practices remains uncertain. ${ }^{71}$

A review of the provincial federations' monthly publications, over two decades, reveals a scattering of articles featuring student centred classroom planning. In one instance, an elementary teacher initiated a project with her class of students who originated from 11 different nationalities; every Friday, she set up a geography class in which students "traveled" to different countries and parents brought in materials for the "trips." The teacher reported a change in attitude and a new comradeship as admiration for the "talents and achievements of other nationalities developed." 72 If a secondary teacher wanted to engage in citizenship education, among the reference books cited in the Ontario curriculum was MacLeod's Citizenship Training: A Handbook for Canadian Schools. Claiming that "Citizenship must be acquired through practice," part 2 of the book documents 18 techniques for integrating citizenship with other subjects. ${ }^{73}$ Likewise, a study of women teachers in Toronto secondary schools suggests that Miss Snell was not alone in her commitment to teaching citizenship and democracy through classroom practice. Kristina Llewllyn study of the "performance" of women teachers in Toronto secondary schools reveals how some teachers negotiated the gender hierarchy of the postwar liberal "democracy" in schools. ${ }^{74}$

\section{Global citizenship education}

As chronicled in the teaching experience of Blanche Snell, the 1950s witnessed interest among Canadian educators, federations, and politicians in addressing human rights and world issues. Educational leaders such as G. Blair Laing, chairman of the Toronto Board of Education, stated in a speech at the Empire Club in $1950^{75}$ that the main purpose of education is democracy; calling for "education for World Brotherhood or World Citizenship." Similarly, Lester B. Pearson in speaking to the members of the FWTAO in 1948 on the "Role of the Teacher in International Affairs" prevailed upon teachers to instruct their students about other countries as the key to "peaceful 
and progressive relations." 76 As well, within federations' publications, teachers were routinely encouraged to support various causes such as the Canadian Appeal for Children to provide food and clothing for children and books for schools. ${ }^{77}$ By 1962 , teachers were invited to expand their knowledge of other countries and promote educational opportunities by signing up for CTF's international development program, Project Overseas, to teach children in the Caribbean, Africa, and Asia. ${ }^{78}$

Because Canada lacks a federal agency to oversee education, no central government agency co-ordinated UNESCO's postwar education programs $;{ }^{79}$ instead, they were funneled through surrogate organizations. In 1947, the Canadian Council for Reconstruction was founded as a voluntary, non-profit organization to assist war torn countries; a constitution was adopted by representatives of 30 organizations, including the Canadian Education Association, the Boy Scouts, and the YWCA, at a conference convened by the Department of External Affairs. ${ }^{80}$ In 1948, Grace Dolmage, co-ordinator of the Winnipeg Child Guidance Clinic, reported to the Canadian Education Association on a recent UNESCO seminar on world understanding through childhood education; that same year, Dr. Fletcher Peacock, director of education in Fredericton, spoke about UNESCO's seminar on teaching about the UN's work for "world understanding... to remove prejudices." ${ }^{81}$ It wasn't long before teachers from across Canada were drawn into the organization. In 1950, Gladys Voycheshin, a Winnipeg teacher, attended the UNESCO seminar as the CTF's representative, ${ }^{82}$ and a UNESCO seminar promoting geography and international understanding was held for teachers at Macdonald College of McGill University. ${ }^{83}$ The Canadian Council for Reconstruction dissolved in the mid-1950s, just before the creation of the Canadian Commission for UNESCO in $1957 .{ }^{84}$ In 1953, UNESCO undertook a large-scale project with a number of secondary schools to "determine to what extent mutual understanding and the elimination of prejudice can be fostered by education"; but it wasn't until 1965 that Oakwood Collegiate in Toronto became the first UNESCOassociated school in Canada. ${ }^{85}$ The lack of a central government agency in the $1950 \mathrm{~s}$ to promote UNESCO in the schools may account for the low profile of the organization among the federal departments and within the provincial curriculum.

The United Nations, however, was featured in the Ontario curriculum in 1951. For the final unit in grade 10 social studies, students were invited to discuss the role of the United Nations under the heading "cooperation is essential for world security." 86 The last assignment in the curriculum, "Canada's place and responsibility in the United Nations," required students to "assemble in a special section of the class looseleaf scrap book evidence of Canada's faith and support of United Nations. Discuss the personal responsibility of each Canadian to United Nations." If at the end of a busy year teachers were able to schedule this assignment, then the students might have discovered that the United Nations Declaration of Human Rights was written by a Canadian, John Humphrey. ${ }^{87}$

\section{School Culture and Citizenship}

School culture played a vital role in shaping a student's daily experience of formal 
education. As we shall see, the four strands of Osborne's model of citizenship teaching were reproduced within student-led clubs in secondary schools in the postwar period. Political efficacy and rights and duties were central to students' understanding of human rights and global citizenship in the United Nations (UN) Clubs that formed after the incorporation of the UN Association in Canada in 1946. ${ }^{88}$ Historian Kenneth Dewar recalls competing in a public-speaking competition sponsored by the UN Association as a formative experience of his schooling in the late 1950s. His public-speaking coach, a social studies teacher, was also a staff sponsor of the school's UN Club. ${ }^{89}$ The UN Clubs' existence seemed to rely on the commitment of a teacher-sponsor, such as Miss Snell. At Lisgar Collegiate in Ottawa, under the supervision of the head of the history department, a UN Club was formed in 1945 to promote "a better understanding of world affairs." It flourished for several years with up to 30 members who organized films, public speaking, and lively debates, but declined in the mid-fifties, shortly before its staff sponsor retired; it was resurrected in 1967 when Lisgar became a certified UNESCO school. ${ }^{90}$

Outside service organizations, such as the Rotary Club, also played a part in fervently promoting global citizenship education among secondary students. Its popular, and highly contested, school-wide public-speaking contests attracted the attention of students, teachers, and school officials. In 1955, for example, Adrienne Poy (later Adrienne Clarkson, governor general of Canada), was one of two winners of the Rotary Club's public-speaking contest who was chosen to represent Canadian students at the student UN Model Assembly. ${ }^{91}$

The Red Cross was another organization which prevailed upon students to increase their awareness of global issues and to act as "good citizens." In 1946, 80,150 student members belonged to the Canadian Junior Red Cross, whose objectives included "health, service and good citizenship." Junior Red Cross branches in Canada were in correspondence with members of the society in 49 countries of the world, promoting "International friendliness" as one of the "essentials of good citizenship." They conducted meetings according to parliamentary procedure, practiced public speaking, and took "their responsibilities as young citizens seriously." 92 In a way that was different and similar, charitable giving was promoted through UNICEF's Hallowe'en fund-raising campaign. By the mid-1950s, various communities across Canada encouraged schools to co-ordinate the successful drive "to eliminate disease, want and misery from the lives of children in less privileged countries." 93

Other clubs continued to thrive as teenage school culture blended social events with service. For example, throughout the 1950s, at one Ontario high school, four of the eight non-athletic school clubs educated members about good citizenship through fund-raising projects such as school dances, benevolent events, and information sessions. The Boys and Girls Hi-Y (affiliates of the YM-YWCA) were involved in charitable services such as purchasing gifts and organizing game nights for the children in a local orphanage and at the hospital, and engaging in political discussions with invited speakers and films. The Welfare Club, formed in 1946, sent money to destitute families in postwar Europe. By the 1950s, this small group of mostly girls promoted "International good will" and "the problems faced by under-privileged 
people." They annually raised money with dances and the Welfare Tea to send to CARE, UNICEF, and the Unitarian Service Committee. ${ }^{94}$

\section{Conclusion}

Dominique Clement's study of social movements and social change reminds us of the importance of understanding the dynamics of public opinion. As he argues, "Human rights are ultimately linked with changes in the law, yet at the same time they are informed by the cultural context of the community they serve.... Human rights are a powerful force because the source of human rights lies not in the law but in human morality. A society with a strong rights culture allows individuals to make rights claims even though, at the time, they are not recognized by the state or even the community around them." To underscore his argument, Clement remarks how "Canadians have come to view themselves as rights-bearing citizens, and this has had a profound impact on the relationship between the state and civil society." 95

In this paper, I am not claiming that the forties and fifties were decades of rampant social justice; systemic barriers to equality and human rights in the postwar period resulted in multiple forms of discrimination in Canada. Even within the material cited here, human rights for the most part was racialized, but not systemically gendered. ${ }^{96}$ Rather, what I am suggesting is that despite the traditional rhetoric of the provincial curriculum, there existed school clubs, quasi-government organizations, and some educators, like Miss Snell, who exposed youth to a range of ideas about social justice, human rights, international development and discrimination at an age when they clearly understood concepts of (in)equality and (in)justice. Within the lived experience of the culture of secondary school clubs, many students gained first hand knowledge of Canadian identity, political efficacy, rights and duties, and social and personal values. Through the routine practice of organizing meetings, taking minutes, preparing reports, inviting speakers, debating topics, resolving conflicts, seeking consensus, fundraising and a host of other tasks, students learned how to take responsibility " in good creative living, at community, national and international levels." As well, this research profiles ways that schooling in the fifties may have influenced, in part, citizens in the 1960s and 1970s to embrace political and social actions. Finally, this study suggests that exposure to ideas of tolerance and individual rights may have contributed to a later understanding of diversity and difference, as expressed in the multiculturalism policies in the 1970s and 1980s, as Canadian. 


\section{Notes}

1 Blanche Snell, "Operating the 'Core' Curriculum," in Education: A Collection of Essays on Canadian Education, vol. 1, 1954-1956 (Toronto: W.J. Gage, 1956), 53-56.

2 Ibid., 55.

3 Ibid., 55.

4 Ibid., 56.

5 York Memo [yearbook] (Toronto, ON: York Memorial Collegiate Institute, 1955), 43.

6 York Memo, 1959, 66.

7 York Memo, 1961, 8.

8 "Students Honoured at Tea," Globe and Mail, March 31, 1960, 19. Following Miss Snell's death in 1972, the Ontario Teachers' Federation created the Blanche E. Snell Estate Fund - recipients of the award must be citizens of a developing country and must return to their own country to work in education; see Ontario Teachers' Federation, "OTF Initiatives: International Assistance," Ontario Teachers' Federation: Your Voice, Your Strength, www.otffeo.on.ca/english/init_assist.php.

9 Robert Gidney, From Hope to Harris (Toronto; University of Toronto Press, 2002); Robert Stamp, The Schools of Ontario (Toronto: University of Toronto, 1999); Amy von Heyking, Creating Citizens (Calgary: University of Calgary Press, 2006); Paul Axelrod, "Beyond the Progressive Education Debate: A Profile of Toronto Schooling in the 1950s," Historical Studies in Education 17, 2 (2005): 227-41.

10 Cynthia R. Commachio, The Dominion of Youth: Adolescence and the Making of Modern Canada (Waterloo: Wilfrid Laurier University Press, 2006), 129-59. See also Michael Gauvreau, "The Protracted Birth of the Canadian 'Teenager': Work, Citizenship, and the Canadian Youth Commission, 1943-1955," in Cultures of Citizenship in Post-War Canada, 1940-1955, ed. Nancy Christie and Michael Gauvreau (Montreal: McGillQueen's University Press, 2003): 201-2.

11 Alan Sears, "Instruments of Policy: How the State Influences Citizenship Education in Canada," Canadian Ethnic Studies 29, 2 (1997).

12 Rebecca Coulter and Helen Harper, eds., History Is Hers: Women Educators in Twentieth Century Ontario (Calgary: Detselig, 2005); Kristina R. Llewellyn, "Gendered Democracy: Women Teachers in Post-War Toronto," Historical Studies in Education I Revue d'histoire de l'éducation 18, 1 (2006): 1-25.

13 Reva Joshee and Lauri Johnson, "Historic Diversity and Equity Policies in Canada," in Transformations in Schooling: Historical and Comparative Perspectives, ed. Kim Tolley (New York: Palgrave MacMillian, 2007).

14 Ken Osborne, "Citizenship Education and Social Studies," in Trends and Issues in Canadian Social Studies, ed. Ian Wright and Alan Sears (Vancouver: Pacific Educational Press, 1997), 45; and Ken Osborne, "Public Schooling and Citizenship Education in Canada," in Educating Citizens for a Pluralistic Society, ed. Rosa Bruno-Jofré and Natalia Aponiuk (Calgary: Canadian Ethnic Studies, 2001), 11-48.

15 Osborne, "Citizenship Education and Social Studies," 49.

16 William Kaplan, The Evolution of Citizenship Legislation in Canada (Ottawa: Multiculturalism and Citizenship Canada, 1991), 20.

17 Cited in Kaplan, The Evolution of Citizenship Legislation in Canada, 17-18.

18 On the significance of this legislation for immigrants, see Harold Troper, "Citizenship Education in Urban Canada," in Citizenship in Transformation in Canada, ed. Yvonne E. Hébert (Toronto: University of Toronto Press, 2002), 150-61.

19 C. R. MacLeod, introduction to Citizenship Training: A Handbook for Canadian Schools (Toronto: J.M. Dent, 1949). See also Alan Sears and Emery J. HyslopMargison, "The Cult of Citizenship Education," in Troubling the Canon of Citizenship Education, ed. George Richardson and David Blades (New York: Peter Lang, 2006), 13-24; Robert Adamoski, Dorothy E. Chunn, and Robert Menzies, eds., Contesting 
Canadian Citizenship: Historical Readings (Peterborough, ON: Broadview, 2002); and Yvonne M. Hebert, ed., Citizenship in Transformation in Canada (Toronto: University of Toronto Press, 2002).

20 R. Brian Howe, "Human Rights in Hard Times: The Post-war Canadian Experience," Canadian Public Administration / Administration Publique du Canada 35, 4 (1992): 466.

21 Christopher MacLennan. Toward the Charter: Canadians and the Demand for a National Bill of Rights, 1929-1960 (Kingston: McGill-Queen's Press, 2003), 3.

22 Madga Fahrni and Robert Rutherdale, introduction to Creating Postwar Canada: 1945-75, ed. Marda Fahrni and Robert Rutherdale (Vancouver: UBC Press, 2008), 3-5; Doug Owram, Born at the Right Time: A History of the Baby-Boom Generation (Toronto: University of Toronto, 1996).

23 Warren Kalbach, The Impact of Immigration on Canada's Population (Ottawa: Dominion Bureau of Statistics, 1961), 348-49.

24 From 1946 to 1958 , more than 29,000 prospective immigrants were rejected as "security risks," and 8,572 people were deported over the same period Ninette Kelley and Michael Trebilcock, The Making of the Canadian Mosiac: A History of Canadian Immigration Policy (Toronto: University of Toronto Press, 1998), 314; Franca Iacovetta, Gatekeepers: Reshaping Immigrant Lives in Cold War Canada (Toronto: Between the Lines, 2006).

25 Kalbach, The Impact of Immigration, 419.

26 Kelley and Trebilcock, The Making of the Canadian Mosiac, 314.

27 Robert Gidney, From Hope to Harris (Toronto; University of Toronto Press, 2002), 27-28. On the postwar objectives of secondary schools, see Robert Stamp, The Schools of Ontario (Toronto: University of Toronto, 1999).

28 Cited in Heidi Bohaker and Franca Iacovetta, "Making Aboriginal People 'Immigrants Too': A Comparison of Citizenship Programs for Newcomers and Indigenous Peoples in Postwar Canada, 1940s-1960s," Canadian Historical Review 90, 3 (September 2009): 428-29.

29 In addition to its mandate, the citizenship branch was responsible for immigration, Indian affairs, the Canadian Citizenship Branch, and Canadian Citizenship Registration Branch. For an analysis on the similarities in immigration and Indian citizenship, see Iocovetta and Bohaker, "Making Aboriginal People "Immigrants Too," 428-29. For an analysis of wartime citizenship policy, see Ivana Caccia, Managing the Canadian Mosaic: Shaping Citizenship Policy, 1939-1945 (Kingston: McGill-Queen’s University Press, 2010).

30 Michael Gauvreau claims that, throughout the 1940s, it was "the emphatically 'public' qualities of youth as producer and citizen, rather than the 'private' nature of the teenager as consumer of leisure and personal relationships, that defined the attitudes of Canadians between the end of World War II and the early 1950s.” Michael Gauvreau, "The Protracted Birth of the Canadian 'Teenager': Work, Citizenship and the Canadian Youth Commission," in Cultures of Citizenship in Post-War Canada, 1940-1955, ed. Nancy Christie and Michael Gauvreau (Montreal: McGill-Queen's Press, 2003), 203.

31 Commachio, The Dominion of Youth, 129. See also Michael Gauvreau, "The Protracted Birth of the Canadian 'Teenager," 201-38.

32 Lorna McLean. "No Short Cuts to Better Days": Education, identity and citizenship in early modern Canada, 1900-1930. Journal of Canadian Studies 41 (2007), 2-26.

33 Alan Sears, "Instruments of Policy: How the State Influences Citizenship Education in Canada," Canadian Ethnic Studies 29, 2 (1997): 7.

34 Ibid., 1.

35 The Guide was originally published in 1950s in the Citizenship Branch's monthly journal, The Citizen. Ottawa. Department of Citizenship and Immigration. Let's Take a Look at Prejudice, Citizenship Guide. Reprinted, 1961. 
36 Brian Low, NFB Kids: Portrayals of Children by the National Film Board of Canada, 1939-89 (Waterloo, ON: Wilfrid Laurier University Press, 2002), 28.

37 Ibid., 29-30.

38 Ibid., 29-40.

39 Sears, "Instruments of Policy," 10.

40 Educational Courier, "Visual Aids on Intercultural Relations," February 1947, 22.

41 To hear a selection of the broadcasts, visit CBC Digital Archives at http://archives.cbc. ca.

42 Educational Courier, "The Editorial Slant...," October 1944, 3; see also CBC Digital Archives at http://archives.cbc.ca.

43 W.D. Rutherford, "Are student discussion groups worth while?" The Bulletin Ontario Secondary School Teachers' Federation (OSSTF) 28(1) February, 1948, 31-2.

44 Janine Brodie. "Reforming Social Justice in Neoliberal Times," Studies in Social Justice 1, 2 (2007): 98.

45 Ronald Faris, The Passionate Educators: Voluntary Associations and the Struggle for Control of Adult Educational Broadcasting in Canada, 1919-1952 (Toronto: Peter Martin, 1975), 101-11.

46 Amy von Heyking, Creating Citizens (Calgary: University of Calgary Press, 2006), 106-7.

47 Eveleen Burns, Civics and Citizenship Grades 7, 8, and 9: A Guide for Teachers, Tentative ed. (Halifax: Department of Education 1957, rev. ed. 1958), 8, 10.

48 Alice Miel, "The School's Fourth R-Relationship," The Educational Courier, December 1946, 5, 34. Reprinted from OHIO schools; "Better Human Relations" The Bulletin (December 1949) 256.

49 Ontario Department of Education, Intermediate Division, 1951 Curriculum: Grades VII, VIII, IX, X (Toronto: Minister of Education, 1951), 58. For an analysis on how the dominant culture continues to pervade social studies curricula, see Kurt W. Clausen, Todd Horton, and Lynee Lemisko, "Democracy and Diversity: A Content Analysis of Selected Contemporary Canadian Social Studies Curricula," Citizenship Teaching and Learning 4, 1 (July 2008): 435-49.

50 Ontario Department of Education, Intermediate Division, 1951 Curriculum, 58-60.

51 Ibid., 58-59.

52 Walt Werner, "Reading Authorship into Texts," Theory and Research in Social Education 28, 2 (Spring 2000): 194.

53 Ontario Department of Education, Intermediate Division, 1951 Curriculum, 60-61.

54 Werner, "Reading Authorship into Texts," 194.

55 Ontario Department of Education, Intermediate Division, 1951 Curriculum, 73-74.

56 Ibid., 85-87.

57 Ibid., 104-6.

58 Ibid., 64-65.

59 Ibid., 66.

60 Werner, "Reading Authorship into Texts," 73.

61 Gidney, From Hope to Harris, 35.

62 Penney Clark, "'Home-Grown Product' or 'Made in America'? History of Social Studies in English Canada," in Trends and Issues in Canadian Social Studies, ed. Ian Wright and Alan Sears (Vancouver, BC: Pacific Educational Press, 1997), 68-99.

63 von Heyking, Creating Citizens, 107.

64 Paul Axelrod, "Beyond the Progressive Education Debate: A Profile of Toronto Schooling in the 1950s," Historical Studies in Education 17, 2 (2005): 227-41.

65 Reva Joshee and Lauri Johnson, "Historic Diversity and Equity Policies in Canada," in Transformations in Schooling: Historical and Comparative Perspectives, ed. Kim Tolley (New York: Palgrave MacMillian, 2007), 111, 114. For an American perspective, see 
Clarence Chatto and Alice Halligan, The Story of the Springfield Plan (New York: Barnes and Noble, 1945).

66 Educational Courier, "Visual Aids on Intercultural Relations," 22.

67 Kathleen Weiler, Women Teaching for Change (South Hadley, MA: Bergin and Garvey, 1988), 1; see also Rebecca Coulter and Helen Harper, eds., History Is Hers: Women Educators in Twentieth Century Ontario (Calgary: Detselig, 2005).

68 von Heyking, Creating Ctiizens, 110.

69 Ibid., 111-112.

70 A. B. Hodgetts. What Culture, What Heritage? (Toronto: OISE, 1968). On racism in history textbooks from post-World War II to the1990s, see Ken Montgomery, "Imagining the Antiracist State: Representations of Racism in Canadian History Textbooks," Discourse: Studies in the Cultural Politics of Education 26, 4 (Dec. 2005): 427-42; and José Igartua, The Other Quiet Revolution (Vancouver: UBC Press, 2006), 63-88.

71 Frank K. Clarke, “'Keep communism out of our schools': Cold War Anti-communism at the Toronto Board of Education, 1948-1951.” Labour / Le Travail 49 (Spring 2002): 93-119. On teachers' fears of using progressive teaching methods during the cold war years in the United States, see Gerard Giordano, Wartime Schools: How World War II Changed American Education (New York: Peter Lang, 2004).

72 C. Slater, "Citizenship_A Class Enterprise," Educational Courier, October 1945, 17, 36.

73 MacLeod, Citizenship Training, 54-64.

74 Kristina R. Llewellyn, "Gendered Democracy: Women Teachers in Post-War Toronto," Historical Studies in Education / Revue d'histoire de l'éducation 18, 1 (2006): 1-25. See also Alison Prentice and Marjorie Theobald, eds., Women Who Taught: Perspectives on the History of Women and Teaching (Toronto: University of Toronto Press, 1991); and Rebecca Priegert Coulter, "Getting Things Done: Donalda J. Dickie and Leadership through Practice," Canadian Journal of Education 28, 4 (2005): 669-99. For a biographical account of an activist teacher's career, see Kate Rousmaniere, Citizen Teacher: The Life and Leadership of Margaret Haley (Albany, NY: State University of New York Press, 2005).

75 G. Blair Laing, "Education Today-Are We in Tune with the Times?" In The Empire Club of Canada Addresses (Toronto: Empire Club Foundation, 1951), 4150. Rpt. online The Empire Club of Canada, http://speeches.empireclub.org/details. asp? $\mathrm{r}=\mathrm{vs} \& \mathrm{ID}=61330 \&$ number $=1$.

76 Pearson, L.B., "Role of the Teacher in International Affairs," Educational Courier, December 1948, 7-8, 34, 36-37.

77 Claire Slater, "A Hand across the Sea," Educational Courier, February 1948, 17, 36.

78 Rebecca Priegert Coulter, "'Girls Just Want to Have Fun': Women Teachers and the Pleasures of the Profession," History Is Hers: Women Educators in Twentieth Century Ontario, ed. R.P. Coulter and H. Harper (Calgary: Detselig, 2005), 220.

79 In 1950, Canada paid \$300,000 a year toward UNESCO's expenses. Montreal Gazette, "Limited Resources Spread Too Thin?" Sept. 7, 1951.

80 Library and Archives Canada (LAC), Canadian Council for Reconstruction through UNESCO (1947-1952) fonds, MSS2245, MG28-I45, R7680-0-0-E.

81 Winnipeg Tribune, "Train Children at Three for Peace, Says Director," Sept. 29, 1948.

82 Montreal Gazette, "Far East Held 'Neglected' in History School Books," Sept. 8, 1950.

83 Montreal Daily Star, "Delegates Attend First UNESCO Seminar," July 18, 1950.

84 LAC, Canadian Council for Reconstruction through UNESCO (1947-1952) fonds; Canada Council for the Arts, Milestones: Forty Years in the Life of the Canada Council (Ottawa: CCA, 1999). 
85 LAC, Canadian Council for Reconstruction through UNESCO (1947-1952) fonds, MG 28 197, vol. 28, folder 3, bulletins 1965-70, UNESCO Associated School in Canada bulletin, n.d.

86 Ibid., 136-39.

87 The previous suggestion recommends that students "prepare biographical sketches of outstanding Canadians such as Dr. Brock Chislom and H. L. Keenleyside, who hold high posts in U.N. organizations.” Ibid., 139.

88 LAC, Canadian Council for Reconstruction through UNESCO (1947-1952) fonds, MG 28, I202, vol. 20, United Nations Association in Canada. Provinces are organized into branches with the central office in Ottawa. In 1961, for example, V. M. Knight of the Halifax Branch, United. Nations Association in Canada, requested that the committee "start organizing immediately to provide the necessary leadership for the community and the schools when the new school term opens in September." Nova Scotia Archives and Records Management (NSA), MG1, vol. 2910, no. 36.

89 Kenneth C. Dewar, "Hilda Neatby’s 1950s and My 1950s." Journal of Canadian Studies 40, 1 (2006): 213.

90 Vox Lycei [yearbook] (Ottawa: Lisgar Collegiate 1966-67), 83.

91 Vox Lycei, 1955-56, 19.

92 George Tuttle, Youth Organizations in Canada: A Reference Manual, prepared for the Canadian Youth Commission (Toronto: Ryerson Press, 1946), 102-3.

93 NSA, Duckworth Collection, MG1, vol. 2910, no. 34, "Organizing Program for Hallowe'en Drive," newspaper clipping, n.d.; Memo to Halifax School Principals from Halifax Hallowe'en UNICEF Committee, n.d.

94 Vox Lycei, 1946.

95 Dominique Clement, Canada's Rights Revolution (Vancouver: UBC Press, 2008) 34.

96 Llewellyn, "Gendered Democracy"; Joan Sangster, Transforming Labour, (Toronto: University of Toronto Press, 2101) p. 35. 